\title{
Comparison of Different Methods of Blood Pressure Measurements from the Arm and the Ankle in Young and Elderly People: A Cross-Sectional Study
}

\author{
Özlem Kaştan ${ }^{1}$ (D), Şengül Akdeniz ${ }^{2}$ (D), Selma Turan Kavradım³ ${ }^{3}$, Zeynep Özer ${ }^{3}$ (1) \\ 'Department of Medical Services and Techniques, Akdeniz University, Vocational School of Health Services, Antalya, Turkey \\ ${ }^{2}$ Department of Health Care Services Elderly Care, Akdeniz University, Vocational School of Health Services, Antalya, Turkey \\ ${ }^{3}$ Department of Internal Medicine Nursing, Akdeniz University, Faculty of Nursing, Antalya, Turkey
}

\begin{abstract}
Objective: In this study, we aimed to compare different methods of measuring blood pressure devices and to investigate the inter-arm and inter-leg difference (IAD and ILD), the ankle brachial index, and variables that affect them in young and elderly participants.

Methods: This study was conducted in Turkey with 150 students studying at a university and 150 individuals aged over 60 , a total of 300 participants. Data regarding the measurements of arm and ankle blood pressures using an automated oscillometric device and an aneroid sphygmomanometer were collected between December 2019 and January 2020 by the researchers.

Results: There was a correlation between the right arm systolic blood pressure and the variable of bodyweight, and measurements made by automatic oscillometry were higher than those made using an aneroid manometer. A large IAD of $\geq 10$ $\mathrm{mmHg}$ was found in $22.7 \%$ of the participants, and large ILD was found in $30 \%$. Mean IAD was associated with bodyweight and body mass index. ILD was greater in men than in women and in older individuals compared with those in younger participants. In addition, low ankle brachial index values of $\leq 0.9$ were found in $2.3 \%$ of the participants.
\end{abstract}

Conclusion: The present data show the results of a comparison of blood pressure measurements in young and old individuals made using different devices and parts of the body. We believe that the findings will create awareness in the researchers and health personnel regarding comparison of IAD and ILD and ankle brachial index in these individuals.

Keywords: Automatic oscillometry, aneroid manometer, arm blood pressure, ankle blood pressure, ankle brachial index, blood pressure measurement, inter-leg differences, inter-arm differences

\section{Genç ve Yaşlı Bireylerde Kol ve Ayak Bileğinden Farklı Kan Basıncı Ölçüm Yöntemlerinin Karşılaştırılması: Kesitsel Bir Çalışma}

Özet

Amaç: Bu çalışmanın amacı genç ve yaşlı bireylerde dijital ve aneroid kan basıncı ölçüm cihazları kullanılarak ölçülen kol ve ayak bileğinden kan basıncı ölçüm değerlerini karşılaştırmak ve ölçüm sonucunu etkileyen değişkenleri araştırmaktır.

Yöntemler: Bu çalışma Türkiye'de bir üniversitede Yaşıı Bakımı bölümünde eğitim-öğretim gören 18-30 yaş arası 150 öğrenci ve yaşlı evlerine kayıtlı 60 yaş üstü 150 birey olmak üzere toplam 300 katııımcı ile yürütülmüştür. Araştırmanın verileri Aralık

Correspondence (iletişim): Şengül Akdeniz, Department of Health Care Services Elderly Care, Akdeniz University, Vocational School of Health Services, Antalya, Turkey

Phone (Telefon): +90 2422274537 E-mail (E-Posta): sengulakdeniz@akdeniz.edu.tr

Submitted Date (Başvuru Tarihi): 14.06.2021 Accepted Date (Kabul Tarihi): 15.09.2021

oCopyright 2021 by Turkish Society of Cardiology - Available online at www.khd.tkd.org.tr

OPEN ACCESS This work is licensed under a Creative Commons Attribution-NonCommercial 4.0 International License. 
2019- Ocak 2020 tarihleri arasında araştırmacılar tarafından otomatik osilometrik cihaz ve aneroid tansiyon aleti kullanılarak kol ve ayak bileğinden tansiyon ölçümü yapılarak gerçekleştirildi.

Bulgular: Sağ kol sistolik kan basıncı ile vücut ağırlığı değişkeni arasında korelasyon bulundu ve otomatik osilometri ile yapılan ölçümlerin aneroid manometre kullanılarak yapılan ölçümlerden daha yüksek olduğu görüldü. Katılımcıların \%22.7'sinde 10 mmHg'dan büyük kollar arası fark ve \%30'unda bacaklar arası ölçümlerde farklılıklar bulundu. Kollar arası ortalama farklııklar ile vücut ağırlığı ve vücut kitle indeksi arasında ilişki saptandı. Bacaklar arası ortalama farklııklar erkeklerde kadınlardan ve yaşlılarda gençlerden daha fazlaydı. Ayrıca, katılımcıların \%2.3'ünde brakiyal indeksi değerleri $\leq 0.9$ altında bulundu.

Sonuç: Mevcut veriler, genç ve yaşlı bireylerde farklı cihazlar ve vücudun farkı bölümleri kullanılarak yapılan kan basıncı ölçümlerinin karşılaştırmalı sonuçlarını göstermektedir. Elde edilen bulguların, genç ve yaşlılarda kollar arası ve bacaklar arası ölçüm farklılıkları ile ayak bileği brakiyal indeksinin karşılaştıııması konusunda araştırmacılar ve sağlık personeline farkındalık sağlayacağı düşünülmektedir.

Anahtar sözcükler: Otomatik osilometri, aneroid manometre, kol kan basıncı, ayak bileği kan basıncı, ayak bileği kol indeksi, kan basıncı ölçümü, bacaklar arası farklar, kollar arası farklar

Cite this article as: Kaştan Ö, Akdeniz Ş, Turan Kavradım S, Özer Z. Comparison of Different Methods of Blood Pressure Measurements from the Arm and the Ankle in Young and Elderly People: A Cross-Sectional Study. Turk J Cardiovasc Nurs 2021;12(29):145-154.

$B_{\mathrm{p}}^{\log }$ lood pressure (BP) measurement is critical for clinical practice. $^{[1]}$ Although many hypertension guidelines have been developed, the American College of Cardiology (ACC)/American Heart Association (AHA) 2017 and European Society of Cardiology (ESC)/European Society of Hypertension 2018 guidelines are two well-established and frequently referenced documents. ${ }^{[1-3]}$ In both guides, emphasis is placed on the accuracy of BP measurements and home BP monitoring. ${ }^{[1-3]}$ Accurate measurement of BP is important for the diagnosis of cardiovascular disease (CVD), better hypertension management, and the detection of disease symptoms. ${ }^{[4]}$

The standard location for BP measurement is the upper arm. Alternative sites to measure BP include the wrist, finger, and ankle. ${ }^{[4]}$ BP should be measured in both arms at the initial assessment ${ }^{[4,5]}$ because the identification of inter-arm differences (IAD) for BP in the arms allows the treatment of hypertension more accurately. ${ }^{[6]}$ However, in many situations, practical problems make it difficult to measure the BP of both arms. ${ }^{[5]}$ A systolic BP IAD $\geq 10$ $\mathrm{mm} \mathrm{Hg}$ would be considered clinically significant and is associated with a greater incidence of CVD. ${ }^{[4,7,8]}$ In addition, low ankle brachial index (ABI) associated with lower extremity artery disease has a predictive value for cardiovascular events and is indicative of advanced atherosclerosis.

Many studies have compared BP, measured in both arms, mostly using the auscultation technique. ${ }^{[9-13]}$ However, no clear conclusions were reached..$^{[10,11,14]}$ In a meta-analysis by Verberk et al. ${ }^{[15]} 14 \%$ of the subjects had an IAD of $10 \mathrm{mmHg}$ or more for systolic BP and reported no BP difference between the right and the left arms. In addition, IAD studies were conducted on hypertensive, normotensive, and elderly patients; patients with diabetes, patients with HIV, and pregnant women; ${ }^{[15]}$ and those with chronic kidney disease ${ }^{[16,17]}$ and peripheral arterial disease. ${ }^{[18]}$ It was observed that these studies were conducted in people of middle age and over (a median age of 56, range 31-79 years). ${ }^{[15]}$ Clark et al. ${ }^{[19]}$ reported that IAD in patients with hypertension was higher than that in non-hypertensive East Asian population than that in Western populations. Therefore, this systematic review and meta-analysis suggested that the prevalence of IAD may vary by ethnicity. ${ }^{[19]}$

An alternative site to measure BP is the ankle. ${ }^{[4,20]}$ Lower extremity blood pressure measured at the ankle is important data that help to diagnose peripheral arterial disease with the ankle-brachial index $(A B I) .{ }^{[20]} A B I$ has been shown to be an efficient method for detecting arterial stenosis in the lower extremities, using $\mathrm{ABI} \leq 0.9$ as a cut-off value. ${ }^{[21]}$ Some studies have suggested that decreased $A B I$ is associated with the risk of CVD ${ }^{[22-24]}$ and recurrent stroke. ${ }^{[25-27]}$ However, other studies showed no association. ${ }^{[2,29]}$ In the studies included in a meta-analysis by Hong et al. ${ }^{[21]}$ with individuals aged $\geq 45$ years, it was observed that the type of device used for the measurement of BP affected the readings. ${ }^{[21]}$ Aneroid/manual sphygmomanometers have become common in clinical settings, ${ }^{[4]}$ and automated oscillometric devices are also frequently used for outpatient BP measurements on the upper arm and wrist. ${ }^{[4,30,31]}$ Roerecke et al. ${ }^{\left[{ }^{32]}\right.}$ stated in a meta-analysis that automated office BP measurement should be the preferred method in routine clinical practice. Both oscillometric devices and manual sphygmomanometers have been assessed in a few studies in the literature. ${ }^{[11,33]}$

To the best of our knowledge, this is the first study to compare IAD, inter-leg differences (ILD), and $A B I$ results in young and old individuals using BP measurement instruments such as aneroid and automated oscillometric devices. We believe that the findings will create awareness in researchers and healthcare personnel regarding the comparison among IAD, ILD, and $A B I$ in these individuals. In addition, we predict that the results of this study will help health personnel in planning the necessary procedures for measuring BP. 


\section{Materials and Methods}

In this study, we aimed to compare different methods and devices for measuring $B P$ and to investigate IAD and ILD, $A B I$, and the variables that affect them in young and older participants.

\section{Study Design}

This was a cross-sectional study.

\section{Participants and Sampling}

This study was conducted in Antalya, Turkey, with 150 students studying at the Aged care department of the health services college of a university, and 150 individuals aged over 60 years registered at old people's homes attached to the Municipality Social Assistance Services Directorate, a total of 300 participants. The eligibility criteria for inclusion comprised the ability to provide verbal or written consent to participate in the study and age above 60 years for the old-age group. Participants were excluded if they were diagnosed with hypertension and had undergone extremity amputation. The purposive sampling method was used for all the samples. One hundred and fifty of the 200 students registered and currently studying in the Aged Care Program of the University Health Services Vocational College in the academic year 2019-2020 agreed to participate in the study.

\section{Data Collection}

Collection of research data was conducted by means of a personal information form created by the researchers and through measurements. The personal information form consisted of questions on sex, age, body weight, and body mass index. Blood pressure measurements were made manually and digitally from the arm and leg between 10 am and $5 \mathrm{pm}$. The comparison analysis was divided into four categories: digital versus manual manometer, young versus older participants, arm versus ankle measurement, and right BP versus left BP. Arm blood pressure was measured in a seated position simultaneously for both arms using an automated oscillometric device equipped with two cuffs. The measurements were made by researchers who were experienced in the fields of medical anatomy and internal medicine nursing. The researchers made the measurements according to the steps for measuring BP and recorded the results on a questionnaire. First, the participants' BP was manually and then digitally measured. It was ensured that different researchers made the manual and digital measurements, and no information regarding the measurements was given to the patients until all measurements were completed. Therefore, the researcher making the manual measurements was prevented from affecting the other results. Before performing systolic BP (SBP) and diastolic BP (DBP) measurements, the participants were given five minutes of rest in a sitting position, after which the BP measurements began. Key steps essential for proper BP measurement are as follows: the proper preparation of the patient in a quiet area, and the patient should be seated in a chair, with the back firmly supported and feet flat on the ground, the arm supported, and with the appropriate size cuff. ${ }^{[1,4]}$ Thus, careful attention was paid in the preparation of the participant and the environment before measurement. Moreover, white coats were not used by the researchers with the aim of preventing the white coat effect. BP measurement steps were followed in accordance with the ESC and AHA guidelines. ${ }^{[2,3]}$

Measurements were made after the participants were given information about the content of the study. The participants were informed by the researchers that the study included BP measurements and a few questions on BP measurement. BP measurement data made in the University Health Services were collected in the laboratory of the school. BP measurement of the older participants was performed in an area in the lobby of the old people's home where they came to spend time during the day where they could lie on their backs. Eating status, smoking status, climbing stairs and emptying their bladders were evaluated before blood pressure measurement of the participants. Their clothing was then loosened on all four limbs, and they were allowed to rest for five minutes. Simultaneous BP measurements were made from the four extremities while supine, first manually and then with the automatic measurement devices, once each at intervals. The lower extremity measurements were made supine. The data collection period lasted approximately 20-30 minutes for each participant.

\section{Characteristics of the Measurement Devices}

The digital and manual BP measurement devices used in the study were those recommended by the guidelines. ${ }^{[1-3]}$ The German licensed ERKA and Swiss licensed Microlife digital and manual blood pressure equipment were calibrated and adjusted for use to be used in the study. For arm and leg BP measurements, we used an oscillometric BP device first device. This had a cuff circumference of $22-42 \mathrm{~cm}$ (size $M$ and $\mathrm{L}$ ) and weighed $354 \mathrm{~g}$ (including batteries). It had a measurement range of $20-280 \mathrm{mmHg} B P$ and $40-200$ beats per minute pulse, a cuff pressure display range of $0-299 \mathrm{mmHg}$, and a pulse accuracy of $5 \%$. The second device was an aneroid manometer for measuring BP. A single researcher performed the measurements. The aneroid manometer was calibrated accurately and had a cuff circumference of $22-32 \mathrm{~cm}$ and weighed $450 \mathrm{~g}$; it had a measurement range of $0-300 \mathrm{mmHg} B P$ and a pressure reduction rate of 2-3 mmHg/s. A digital scale with $100 \mathrm{~g}$ sensitivity was used to measure bodyweight, and a rigid measure was used to measure height. 


\section{Ethical Considerations}

Institutional permission to conduct the study was first obtained from the Health Services Vocational College of the university and from the municipality. Permission for the study was obtained from the Akdeniz University Faculty of Medicine clinical research ethics committee (05.07.2019/No. 300) of the university. Verbal and written approval was obtained from the participants who agreed to participate in the research after being informed that their participation was voluntary and that a decision not to participate would not affect their status. When a significant difference was seen in BP values, the individual was directed to go to a health institution for a cardiovascular assessment. This study was conducted in accordance with the principles of the Helsinki Declaration.

\section{Data analyses}

The Statistical Package for Social Sciences version 23.0 (IBM SPSS Corp., Armonk, NY, USA) was used for statistical anal-

\begin{tabular}{|c|c|c|c|}
\hline $\begin{array}{l}\text { Participant } \\
\text { characteristics }\end{array}$ & $\begin{array}{l}\text { Young } \\
n=150\end{array}$ & $\begin{array}{l}\text { Elderly } \\
n=150\end{array}$ & Total \\
\hline \multicolumn{4}{|l|}{ Gender } \\
\hline Female & $105(70 \%)$ & 79 (52.7\%) & $184(61.3 \%)$ \\
\hline Male & $45(30 \%)$ & $71(47.3 \%)$ & $116(38.7 \%)$ \\
\hline Age (years) $\bar{X} \pm S D$ & $19.85 \pm 1.32$ & $67.45 \pm 6.93$ & $43.59 \pm 24.43$ \\
\hline Weight $\bar{X} \pm S D(k g)$ & $60.24 \pm 9.48$ & $71.98 \pm 9.67$ & $66.11 \pm 11.2$ \\
\hline BMI $\left(\mathrm{kg} / \mathrm{m}^{2}\right)$ & $21.42 \pm 2.90$ & $26.91 \pm 3.85$ & $24.16 \pm 4.37$ \\
\hline \multicolumn{4}{|l|}{ Smoking } \\
\hline Smoker & $40(26.7 \%)$ & $3(2 \%)$ & $43(14.3 \%)$ \\
\hline Non-smoker & $110(73.3 \%)$ & $147(98 \%)$ & 257 (85.7\%) \\
\hline \multicolumn{4}{|l|}{ Exercise } \\
\hline Exercises & $20(13.3 \%)$ & 77 (51.3\%) & 97 (32.3\%) \\
\hline No exercise & $130(86.7 \%)$ & $73(48.7 \%)$ & 203 (67.7\%) \\
\hline
\end{tabular}

ysis. Descriptive statistics were used for categorical variables, and these were expressed as numbers, percentages, means, and mean differences. Before comparisons were made, the data were examined for normal distribution. For normal distribution, skewness and kurtosis values were used and were established as having normal distribution in the range +1.5 to $-1.5 .^{[34]}$ We used the $t$ test to test group differences in mean systolic and diastolic BP. Inter-arm BP difference was evaluated using the paired t-test. Comparisons of BP data were performed using paired $t$-tests and independent $t$-tests. Multilinear and logistic regression analyses and odds ratio were also used. Statistical significance was defined as a 2 -sided $p$ value of $<0.05$.

\section{Results}

\section{Characteristics of the Study Participants}

A total of 300 participants aged $43.59 \pm 24.43$ years (mean $\pm S D$; range 18-95 years) were recruited. The general characteristics of the study participants are presented in Table 1.

\section{Results of Arm Blood Pressure Measurements}

We performed arm BP measurements with an aneroid manometer and by automatic oscillometry in young and older participants. The comparison analysis was divided into three categories: aneroid manometer versus automatic oscillometry, young versus older participants, and right versus left arm BP measurement.

\section{Factors Associated with Arm Blood Pressure}

Table 2 presents the factors associated with arm BP of the study participants.

\section{Comparisons of Arm Blood Pressure with Different Types of Device and Different Participants}

Table 3 presents comparisons of arm BP measurement with different types of devices and different participants.

\section{Large Inter-Arm Difference in Blood Pressure}

Table 4 presents the factors associated with large IAD in BP.

\begin{tabular}{|c|c|c|c|c|c|c|c|c|c|c|c|c|}
\hline & \multicolumn{3}{|c|}{ Left arm SBP } & \multicolumn{3}{|c|}{ Left arm DBP } & \multicolumn{3}{|c|}{ Right arm SBP } & \multicolumn{3}{|c|}{ Right arm DBP } \\
\hline & Beta & $t$ & $\mathbf{p}$ & Beta & $t$ & $\mathbf{p}$ & Beta & $t$ & $\mathbf{p}$ & Beta & $t$ & $\mathbf{p}$ \\
\hline Sex & 0.076 & 1.30 & 0.194 & 0.093 & 1.33 & 0.184 & 0.055 & 0.99 & 0.318 & 0.026 & 0.38 & 0.701 \\
\hline Group (old/young) & 0.434 & 6.12 & $0.000 *$ & 0.196 & 2.30 & 0.022 & 0.505 & 7.51 & 0.000 & 0213 & 2.55 & 0011 \\
\hline BMI & 0.036 & 0.307 & 0.759 & 0.125 & 0.90 & 0.368 & -0.029 & -0.26 & 0.794 & 0.151 & 1.10 & 0.269 \\
\hline Weight & 0.180 & 1.66 & 0.097 & -0.014 & -0.11 & 0.912 & 0.238 & 2.33 & 0.020 & 0.023 & 0.181 & 0.856 \\
\hline Exercise & -0.004 & -0.06 & 0.945 & 0.082 & 1.31 & 0.190 & 0.050 & 1.00 & 0.316 & 0.081 & 1.31 & 0.190 \\
\hline Smoking & -0.010 & -0.19 & 0.844 & 0.003 & 0.05 & 0.190 & 0.041 & 0.85 & 0.395 & 0.017 & 0.27 & 0.782 \\
\hline
\end{tabular}

SBP: systolic blood pressure; DBP: diastolic blood pressure; BMI: body mass index 


\begin{tabular}{|c|c|c|c|c|c|}
\hline Old & $133.82 \pm 15.60$ & $74.39 \pm 7.70$ & Old & $131.77 \pm 15.48$ & $73.91 \pm 7.80$ \\
\hline $\mathrm{p} / \mathrm{F}$ & $0.000 / 1.493$ & $0.000 / 5.921$ & $\mathrm{p} / \mathrm{F}$ & $0.000 / 6.854$ & $0.000 / 2.612$ \\
\hline Aneroid Manometer LA & SBP $\bar{X} \pm S D$ & DBP $\bar{X} \pm S D$ & Aneroid manometer RA & SBP $\bar{X} \pm S D$ & $\mathrm{DBP} \overline{\mathrm{X}} \pm \mathrm{SD}$ \\
\hline Young & $112.08 \pm 9.54$ & $70.27 \pm 8.43$ & Young & $110.81 \pm 9.79$ & $69.75 \pm 8.24$ \\
\hline Old & $126.79 \pm 14.48$ & $70.07 \pm 8.67$ & Old & $125.75 \pm 12.91$ & $70.12 \pm 9.38$ \\
\hline $\mathrm{p} / \mathrm{F}$ & $0.000 / 25.29$ & $0.834 / 0.140$ & $\mathrm{p} / \mathrm{F}$ & $0.000 / 11.044$ & $0.720 / 2.222$ \\
\hline Automatic oscillometry & $123.79 \pm 17.86$ & $72.17 \pm 8.84$ & Automatic oscillometry & $121.31 \pm 17.00$ & $71.36 \pm 8.57$ \\
\hline $\mathrm{p} / \mathrm{t}$ & $0.000 / 4.889$ & $0.001 / 3.30$ & $\mathrm{p} / \mathrm{t}$ & $0.000 / 4.06$ & $0.013 / 2.49$ \\
\hline Mean (Lower/Upper) & $4.35(2.60 / 6.10)$ & $2.00(0.81 / 3.19)$ & Mean (Lower/Upper) & $3.02(1.56 / 4.49)$ & $1.42(0.29 / 2.55)$ \\
\hline Automatic oscillometry & SBP $\overline{\mathrm{X}} \pm \mathrm{SD}$ & DBP $\bar{X} \pm S D$ & Aneroid manometer & SBP $\overline{\mathrm{X}} \pm \mathrm{SD}$ & DBP $\bar{X} \pm S D$ \\
\hline LA & $123.79 \pm 17.86$ & $72.17 \pm 8.84$ & LA & $119.44 \pm 14.29$ & $70.17 \pm 8.54$ \\
\hline RA & $121.31 \pm 17.00$ & $71.36 \pm 8.57$ & RA & $118.28 \pm 13.67$ & $69.94 \pm 8.82$ \\
\hline $\mathrm{p} / \mathrm{t}$ & $0.000 / 3.76$ & $0.048 / 1.98$ & $\mathrm{p} / \mathrm{t}$ & $0.013 / 2.49$ & $0.594 / 0.534$ \\
\hline Mean (Lower/Upper) & $2.48(1.18 / 3.77)$ & $0.807(0.009 / 1.605)$ & Mean (Lower/Upper) & $1.15(0.24 / 2.06)$ & $0.233(-0.62 / 1.09)$ \\
\hline
\end{tabular}

\begin{tabular}{|c|c|c|c|c|}
\hline Variables & $\mathbf{p}$ & SBP (right-left) $\geq 10$ Odds ratio* $(95 \% \mathrm{CI})$ & $\mathbf{p}$ & DBP (right-left) $\geq 10$ Odds ratio* $(95 \% \mathrm{Cl})$ \\
\hline Group (young/old) & 0.535 & $1.357(0.518-3.557)$ & 0.695 & $0.770(0.209-2.835)$ \\
\hline Sex & 0.224 & $0.628(0.297-1.328)$ & 0.094 & $0.407(0.142-1.167)$ \\
\hline Weight & $0.001^{*}$ & $1.110(1.041-1.183)$ & $0.030^{*}$ & $1.096(1.009-1.191)$ \\
\hline BMI & $0.017^{*}$ & $0.802(0.669-0.962)$ & 0.133 & $0.835(0.660-1.056)$ \\
\hline LA systolic & $0.000^{*}$ & $1.065(1.033-1.098)$ & $0.014^{*}$ & $0.993(0.954-1.034)$ \\
\hline LA diastolic & $0.014^{*}$ & $0.942(0.898-0.988)$ & 0.580 & $0.984(0.928-1.043)$ \\
\hline RA systolic & $0.009^{*}$ & $0.957(0.926-0.989)$ & 0.746 & $1.045(1.009-1.082)$ \\
\hline RA diastolic & & & 0.197 & $0.984(0.928-1.043)$ \\
\hline
\end{tabular}

BMI: body mass index; RA: Right arm; LA: Left arm; IAD: inter-arm difference; BP: blood pressure

\section{Results of Leg Blood Pressure Measurements}

We performed leg BP measurements with the aneroid manometer and by automatic oscillometry in young and older participants. The comparison analysis was divided into three categories: automatic oscillometry versus aneroid manometer, young versus older participants, and right versus left leg BP.

\section{Factors Associated with Leg Blood Pressure}

Table 5 presents the factors associated with leg BP and the ILD of the study participants.

\section{Comparisons of Ankle Blood Pressure with Different Types of Devices and Different Participants}

Table 6 presents comparisons of ankle BP measurement with different types of devices and different participants. 


\begin{tabular}{|c|c|c|c|c|c|c|c|c|c|}
\hline \multirow[b]{2}{*}{ Variables } & \multicolumn{3}{|c|}{ ILD } & \multicolumn{3}{|c|}{ Right ankle SBP } & \multicolumn{3}{|c|}{ Right ankle DBP } \\
\hline & Beta & $t$ & $\mathbf{p}$ & Beta & $t$ & $\mathbf{p}$ & Beta & $t$ & $\mathbf{p}$ \\
\hline Sex & -0.159 & -2.24 & $0.026 *$ & 0.144 & 2.08 & $0.038 *$ & -0.021 & -0.297 & 0.766 \\
\hline Group (old/young) & 0.156 & 1.81 & 0.071 & 0.086 & 1.05 & 0.292 & -0.260 & -3.09 & $0.002^{*}$ \\
\hline BMI & -0.321 & -2.26 & 0.024 & -0.127 & -0.925 & 0.355 & -0.043 & -0.312 & 0.755 \\
\hline Weight & 0.291 & 2.21 & 0.27 & 0.289 & 2.26 & $0.024^{*}$ & 0.394 & 3.08 & 0.002 \\
\hline Exercise & -0.009 & -0.14 & 0.886 & 0.084 & 1.34 & 0.180 & -0.006 & -0.099 & 0.921 \\
\hline Smoking & 0.116 & 1.87 & 0.061 & -0.022 & -0.362 & 0.718 & 0.000 & 0.002 & 0.999 \\
\hline
\end{tabular}

SBP: systolic blood pressure; DBP: diastolic blood pressure; BMI: body mass index; ILD: inter-leg difference; BP: blood pressure

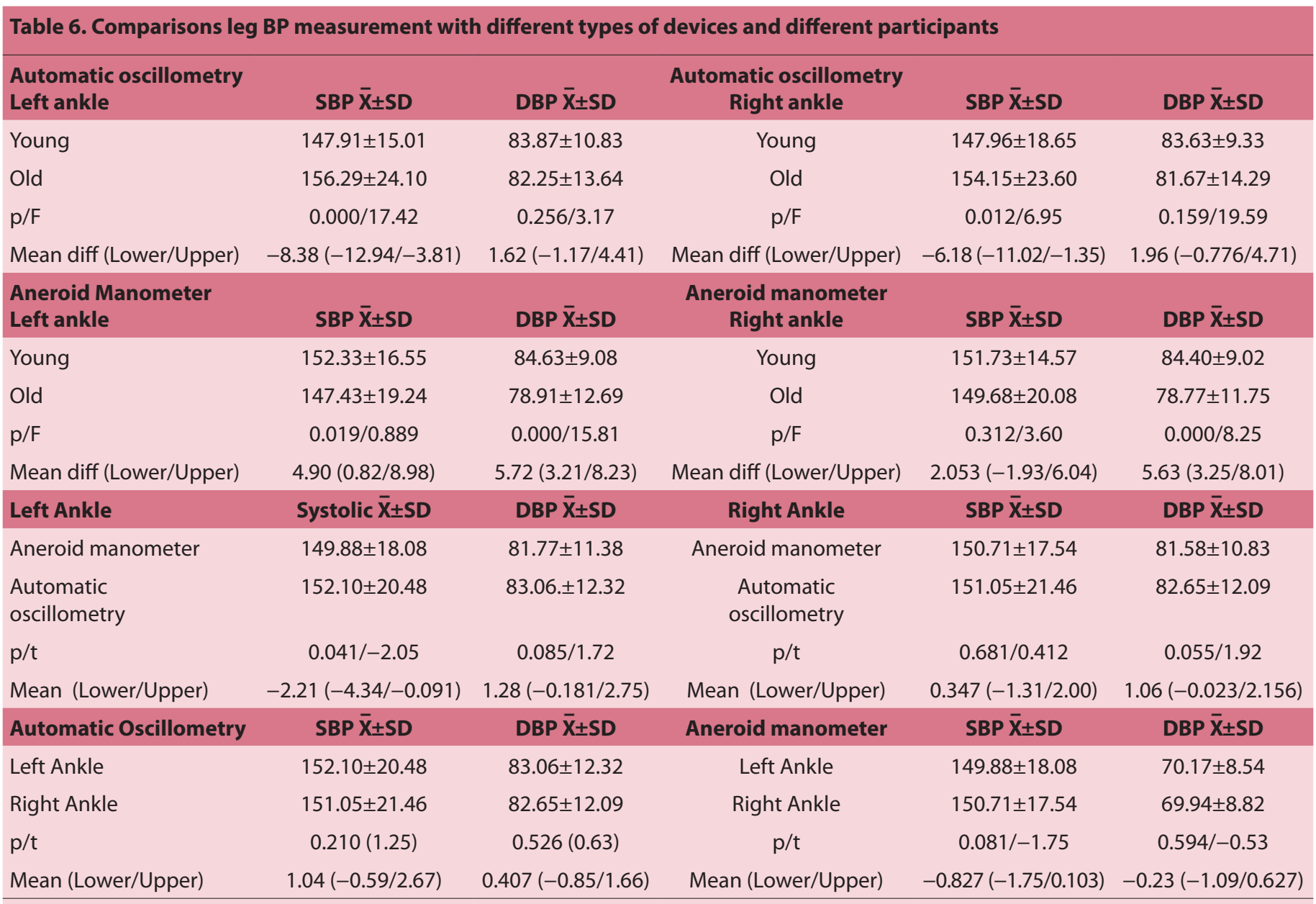

SBP: systolic blood pressure; DBP: diastolic blood pressure; Lower- upper: $95 \%$ Cl; SD: standard deviation; diff: difference; BP: blood pressure

\section{Comparisons of Arm and Leg Blood Pressure Measurements}

Comparisons of arm, wrist, and leg BP measurements with different types of devices and different participants are shown in Table 7.

\section{Comparisons of Ankle brachial index Blood Pressure Measurements}

Comparisons of ankle brachial index BP measurements with different types of devices and different participants are shown in Table 8.

\section{Discussion}

To the best of our knowledge, this is the first study to compare mean BP differences in young and older individuals using 2 measurement devices and to examine factors related to BP in the general Turkish population. The majority of studies in the literature based on BP differences are con- 


\begin{tabular}{|c|c|c|c|c|c|}
\hline Left Ankle & $152.10 \pm 20.48$ & $83.06 \pm 12.32$ & Right Ankle & $151.05 \pm 21.46$ & $82.65 \pm 12.09$ \\
\hline $\mathrm{p} / \mathrm{t}$ & $0.000 /-21.422$ & $0.000 /-12.02$ & $\mathrm{p} / \mathrm{t}$ & $0.000 /-22.36$ & $0.000 /-13.31$ \\
\hline Aneroid manometer & SBP $\overline{\mathbf{X}} \pm \mathrm{SD}$ & DBP $\overline{\mathrm{X}} \pm \mathrm{SD}$ & Aneroid manometer & SBP $\bar{X} \pm S D$ & DBP $\bar{X} \pm S D$ \\
\hline Left Brachial & $119.44 \pm 14.29$ & $70.17 \pm 8.54$ & Right Brachial & $118.28 \pm 13.67$ & $69.94 \pm 8.82$ \\
\hline Left Ankle & $149.88 \pm 18.08$ & $81.77 \pm 11.38$ & Right Ankle & $150.71 \pm 17.54$ & $81.58 \pm 10.83$ \\
\hline
\end{tabular}

\begin{tabular}{|c|c|c|c|}
\hline$A B I$ & SBP $\bar{X} \pm S D$ & $\mathrm{ABI}$ & SBP $\bar{X} \pm S D$ \\
\hline Young & $1.31 \pm 0.20$ & Female & $1.24 \pm 0.21$ \\
\hline Old & $1.17 \pm 0.19$ & Male & $1.25 \pm 0.19$ \\
\hline $\mathrm{p} / \mathrm{F}$ & $0.000 / 0.178$ & $\mathrm{p} / \mathrm{F}$ & $0.585 / 1.86$ \\
\hline $\begin{array}{l}\text { Mean diff } \\
\text { (Lower/Upper) }\end{array}$ & $\begin{array}{c}0.14 \\
(0.09 / 0.18)\end{array}$ & $\begin{array}{c}\text { Mean diff } \\
\text { (Lower/Upper) }\end{array}$ & $\begin{array}{c}-0.013 \\
(-0.06 / 0.035)\end{array}$ \\
\hline
\end{tabular}

ducted with middle-aged and older individuals, and those with various chronic illnesses have been included in these studies. ${ }^{[1,21,35]}$ However, it was observed that there were relatively fewer studies comparing BP differences in young and older people. ${ }^{[15,36]}$ We believe that this study will raise awareness in researchers and healthcare personnel regarding the differences in BP in people according to age and the part of the body where the measurement is made.

In this study, the SBP and DBP measurements of older individuals were higher than those in younger individuals. It was seen that mean SBP in older subjects was 130 $\mathrm{mmHg}$; whereas in younger subjects, it was $110 \mathrm{mmHg}$. When comparing the 2 guideline definitions of hypertension, ESC/ESH defines hypertension as $>140 / 90 \mathrm{mmHg}$ $B P$, whereas the ACC/AHA guidelines define it as $\geq 130 / 80$ $\mathrm{mmHg} \mathrm{BP}^{[1-3]}$ Thus, BP measurement results in older individuals show marginal hypertension. Mean differences in SBP and DBP in the young and older individuals were -20 $\mathrm{mmHg}$ and $-4 /-5 \mathrm{mmHg}$, respectively. Similar to the results of our study, Kawabe and Saito ${ }^{[37]}$ indicated that older ( $\geq 40$ years) subjects showed higher hypertension than those under 40 years of age. Older patients are more likely to have hypertension ${ }^{[31]}$ because with aging, large arteries undergo significant changes and increase in arterial stiffness. ${ }^{[38]}$ In addition, older patients are more likely to have comorbidities such as renal impairment and atherosclerotic vascular disease. ${ }^{[3]}$ Guidelines state that the prevalence of hypertension increases with age, with a prevalence of $60 \%$ in those over the age of 60 years and $75 \%$ in those over the age of 75 years. ${ }^{[3]}$

It was found in this study that mean left arm SBP and DBP were higher than those in the right arm. Multiple guidelines state that in BP measurement, there may be differences between the arms and that both should be measured at the first examination. ${ }^{\left[{ }^{[1]}\right.}$ If there is a difference in $\mathrm{BP}$, the arm with higher values should be used for BP measurements. ${ }^{[39]}$ The results of many studies were examined; however, no clear conclusions were reached regarding which arm gives higher values than the other. ${ }^{[9-13]}$ In contrast to our study, Cassidy and Jones ${ }^{[9]}$ reported that the right arm BP tends to be higher than the left arm BP. Cassidy and Jones ${ }^{[9]}$ also stated that if one arm is to be preferred for clinical BP measurement purposes, then it should be the right arm. Tak et al. ${ }^{[39]}$ stated that right arm BP was significantly higher than the left. In a meta-analysis by Verberk et al. ${ }^{[15]}$ it was reported that there was no BP difference between the right and left arms.

The mean IAD in our study was $7.90+8.58 \mathrm{mmHg}$ for SBP and $4.96+5.03$ for DBP. Large IAD was found in SBP in $22.7 \%$ of participants and in DBP in $10.3 \%$. In a meta-analysis study by Verberk et al. ${ }^{[15]}$ SBP and DBP showed a mean absolute IAD of 5.4 and $3.6 \mathrm{mmHg}$, respectively. Arnett et al. ${ }^{[40]}$ found that $1.6 \%$ of subjects for DBP and $9.2 \%$ of subjects for SBP had an inter-arm DBP difference of $10 \mathrm{mmHg}$ or more. Tak et al. ${ }^{[39]}$ indicated that in $20.9 \%$ (SBP) and $7.2 \%$ (DBP) of the 
patients, the IAD of BP was more than $10 \mathrm{mmHg}$; however, differences of $1.4 \%$ to $39 \%$ are widely reported. ${ }^{[11,14,41]}$ In a meta-analysis by Verberk et al. ${ }^{[15]} 14 \%$ of the subjects had an IAD of $10 \mathrm{mmHg}$ or more for systolic BP.

In our study, a correlation was found between right arm SBP and the variable of weight; as weight increased, SBP also increased. The odds ratio showed that a large IAD in SBP was associated with weight, body mass index, and systolic BP. However, it was seen that mean IAD did not vary according to age or sex. Similar to our study, Brown et al. ${ }^{[42]}$ found strong associations of BMI with hypertension. Dua et al. ${ }^{[43]}$ observed that there was a positive correlation between $\mathrm{BMI}$, fat percentage, and BP. Rosenberger et al. ${ }^{[44]}$ stated that the factors most likely to be associated with IAD in $\mathrm{BP}$ were non-married status and hypertension, followed by older age. Large IAD in BP was associated with obesity and higher systolic $\mathrm{BP}_{1}^{[40]} \mathrm{BMI}$, and mean $\mathrm{SBP}^{[5]}$ but were not associated with age. ${ }^{[39]}$ In addition, it was found that the number of measurements made affected the IAD in SBP. In the meta-analysis by Verberk et al. ${ }^{[15]}$, when BP was measured successively rather than at the same moment, and when only a single BP measurement was made rather than multiple measurements, it was shown that there was a greater relative risk of obtaining an IAD of $\geq 10 \mathrm{mmHg} .{ }^{[15]}$ Therefore, in calculating mean IAD in this study, analysis was made using the second measurement results, that is, the BP measurement results taken with the oscillometric device.

The SBP and DBP measurements made by automatic oscillometry in this study were $3-4 \mathrm{mmHg}$ and $1-2 \mathrm{mmHg}$ higher than those made with the aneroid manometer. In a study by Graves and Grossardt ${ }^{[45]}$ it was shown that BP results obtained by oscillometric methods were higher than auscultatory results performed by a nurse. In another study, aneroid and digital sphygmomanometers were compared, and the digital BP result was found to be higher than that made using the aneroid. ${ }^{[46]}$ It was seen that studies using both measurement instruments together were few in number and that automated oscillometric devices were preferred in the studies. ${ }^{[15]}$ In a comparative study by Shahbabu et al. ${ }^{[46]}$ it was stated that an aneroid device had better accuracy than a digital device when compared with a mercury sphygmomanometer.

In our study, results show ankle SBP to be higher than arm SBP. Ankle SBP and DBP measurements were higher in older subjects than those in the younger subjects. In a systematic review and meta-analysis by Sheppard et al. ${ }^{[36]}$, it was stated that ankle SBP was $17.0 \mathrm{mmHg}$ higher than arm SBP. In our study also, large IAD in BP was seen in $30 \%$ of the participants, and BP was higher in men and older individuals than in women and younger individuals, respectively. In healthy individuals, ankle SBP is slightly higher than arm SBP. ${ }^{[4]}$ Low ankle BP could be indicative of atheroma or atherosclerosis, and high ankle pressures might reflect arterial stiffness or arteriosclerosis of the vessel wall. ${ }^{[47]}$ In our study, $A B I$ was seen to be lower in the older individuals than in younger subjects. However, $A B I$ did not vary according to sex. A low $A B I$ (i.e., <0.9) indicates lower extremity artery disease ${ }^{[3]}$ and also an increase in CVD risk. ${ }^{\left[{ }^{[8]}\right.}$ Our study results show that low $A B I$ values of $\leq 0.9$ were found in $2.3 \%$ of the participants. ${ }^{[47]}$

\section{Study Limitations}

Our study had several limitations, including relatively small sample size. Second, the BP measurements were made on a single day in an office setting at only 2 centers. Third, we could not exclude individuals with subclavian stenosis because data for angiography or imaging studies were unavailable. Finally, we measured BP only twice with 2 devices.

\section{Conclusion}

The present data show the results of a comparison of BP measurements made with different measuring instruments and on different parts of the body in young and older individuals. It was shown that BP measurements were higher in older individuals, left arm BP was higher than right arm BP, ankle SBP was higher than arm SBP, and that $A B I$ was low in older individual. The results of this study also showed that BP measurements made by oscillometry were higher than those made with an aneroid manometer and that SBP correlated with body weight and large IAD with BMI. We believe that this study will create awareness in researchers and healthcare personnel regarding the comparison of BP differences according to the measurement devices, different anatomical sites, and age. We also believe that implementing a comparison of upper and lower extremities at the stage of evaluating routine vital findings in the nursing course curriculum will enable students to recognize the differences.

Ethics Committee Approval: Ethics committee approval was received for this study from the ethics committee of Akdeniz University Faculty of Medicine (Date: 05.07.2019, No. 300).

Informed Consent: Verbal and Written informed consent was obtained from participants who participated in this study.

Peer-review: Externally peer-reviewed.

Authorship Contributions: Concept: Ö.K., Ş.A.; Design: Ö.K., Ş.A., S.TK., Z.Ö.; Supervision: Z.Ö.; Materials: Ö.K., Ş.A.; Data Collection and/or Processing: Ö.K., Ş.A.; Analysis and/or Interpretation: S.TK., Z.Ö.; Literature Search: Ö.K., S..A., S.TK., Z.Ö.; Writing: Ö.K., Ş.A., S.TK., Z.Ö.; Critical Revision: Ö.K., Ş.A., S.TK., Z.Ö.

Acknowledgements: We would like to thank the elderly individuals and the Elderly Care Department of the Health Services students who participated in the study. 
Conflict of Interest: The authors have no conflicts of interest to declare.

Financial Disclosure: The authors declared that this study has received no financial support.

\section{References}

1. Bakris G, Ali W, Parati G. ACC/AHA Versus ESC/ESH on Hypertension Guidelines: JACC Guideline Comparison. J Am Coll Cardiol 2019;73(23):3018-26. [Crossref]

2. Whelton PK, Carey RM, Aronow WS, Casey DE, Collins KJ, Dennison Himmelfarb C, et al. 2017 ACC/AHA/AAPA/ABC/ ACPM/AGS/APhA/ASH/ASPC/NMA/PCNA Guideline for the Prevention, Detection, Evaluation, and Management of High Blood Pressure in Adults. J Am Coll Cardiol 2018;71(19):e127. [Crossref]

3. Williams B, Mancia G, Spiering W, Agabiti Rosei E, Azizi M, Burnier M, et al. 2018 ESC/ESH Guidelines for the management of arterial hypertension: The Task Force for the management of arterial hypertension of the European Society of Cardiology (ESC) and the European Society of Hypertension (ESH). Eur Heart J 2018;39(33):3021-104. [Crossref]

4. Muntner P, Shimbo D, Carey RM, Charleston JB, Gaillard T, Misra S, et al. Measurement of Blood Pressure in Humans: A Scientific Statement From the American Heart Association. Hypertension 2019;73(5):e35-e66. [Crossref]

5. Song BM, Kim HC, Shim J-S, Lee MH, Choi DP. Inter-Arm Difference in Brachial Blood Pressure in the General Population of Koreans. Korean Circ J 2016;46(3):374-83. [Crossref]

6. Gerhard-Herman MD, Gornik HL, Barrett C, Barshes NR, Corriere MA, Drachman DE, et al. 2016 AHA/ACC Guideline on the Management of Patients With Lower Extremity Peripheral Artery Disease: Executive Summary: A Report of the American College of Cardiology/American Heart Association Task Force on Clinical Practice Guidelines. J Am Coll Cardiol 2017;69(11):1465-508. [Crossref]

7. Perloff D, Grim C, Flack J, Frohlich ED, Hill M, McDonald M, et al. Human blood pressure determination by sphygmomanometry. Circulation 1993;88(5 Pt 1):2460-70. [Crossref]

8. Schwartz CL, Clark C, Koshiaris C, Gill PS, Greenfield SM, Haque SM, et al. Interarm Difference in Systolic Blood Pressure in Different Ethnic Groups and Relationship to the "White Coat Effect": A Cross-Sectional Study. Am J Hypertens 2017;30(9):884-91. [Crossref]

9. Cassidy $\mathrm{P}$, Jones K. A study of inter-arm blood pressure differences in primary care. J Hum Hypertens 2001;15(8):519-22. [Crossref]

10. Clark CE, Campbell JL, Powell RJ, Thompson JF. The inter-arm blood pressure difference and peripheral vascular disease: cross-sectional study. Fam Pract 2007;24(5):420-6. [Crossref]

11. Eguchi K, Yacoub M, Jhalani J, Gerin W, Schwartz JE, Pickering TG. Consistency of blood pressure differences between the left and right arms. Arch Intern Med 2007;167(4):388-93. [Crossref]

12. Kimura A, Hashimoto J, Watabe D, Takahashi H, Ohkubo T, Kikuya $\mathrm{M}$, et al. Patient characteristics and factors associated with inter-arm difference of blood pressure measurements in a general population in Ohasama, Japan. J Hypertens 2004;22(12):2277-83. [Crossref]
13. Pesola GR, Pesola HR, Lin M, Nelson MJ, Westfal RE. The normal difference in bilateral indirect blood pressure recordings in hypertensive individuals. Acad Emerg Med 2002;9(4):3425. [Crossref]

14. Lane D, Beevers M, Barnes N, Bourne J, John A, Malins S, et al. Inter-arm differences in blood pressure: when are they clinically significant? J Hypertens 2002;20(6):1089-95. [Crossref]

15. Verberk WJ, Kessels AGH, Thien T. Blood Pressure Measurement Method and Inter-Arm Differences: A Meta-Analysis. Am J Hypertens 2011;24(11):1201-8. [Crossref]

16. Agarwal R, Bunaye Z, Bekele DM. Prognostic significance of between-arm blood pressure differences. Hypertension 2008;51(3):657-62. [Crossref]

17. Quiroga B, Galan I, Garcia de Vinuesa S, Goicoechea M, Verdalles $\mathrm{U}$, Luno J. Interarm systolic blood pressure as a predictor of cardiovascular events in patients with chronic kidney disease. Nephrol Dial Transplant 2015;30(5):801-6. [Crossref]

18. Aboyans V, Criqui MH, McDermott MM, Allison MA, Denenberg JO, Shadman R, et al. The vital prognosis of subclavian stenosis. J Am Coll Cardiol 2007;49(14):1540-5. [Crossref]

19. Clark CE, Taylor RS, Shore AC, Campbell JL. Prevalence of systolic inter-arm differences in blood pressure for different primary care populations: systematic review and meta-analysis. Br J Gen Pract 2016;66(652):e838-e47. [Crossref]

20. Bundo M, Urrea M, Munoz-Ortiz L, Perez C, Llussa J, Fores R, et al. Measurement of the ankle brachial index with a non-mercury sphygmomanometer in diabetic patients: a concordance study. BMC Cardiovasc Disord 2013;13:15. [Crossref]

21. Hong JB, Leonards CO, Endres M, Siegerink B, Liman TG. Ankle-Brachial Index and Recurrent Stroke Risk: Meta-Analysis. Stroke 2016;47(2):317-22. [Crossref]

22. Herraiz-Adillo A, Soriano-Cano A, Martinez-Hortelano JA, Garrido-Miguel M, Mariana-Herraiz JA, Martinez-Vizcaino V, et al. Simultaneous inter-arm and inter-leg systolic blood pressure differences to diagnose peripheral artery disease: a diagnostic accuracy study. Blood Press 2018;27(2):112-9. [Crossref]

23. Male S, Coull A, Murphy-Black T. Preliminary study to investigate the normal range of Ankle Brachial Pressure Index in young adults. J Clin Nurs 2007;16(10):1878-85. [Crossref]

24. Miname M, Bensenor IM, Lotufo PA. Different methods of calculating ankle-brachial index in mid-elderly men and women: the Brazilian Longitudinal Study of Adult Health (ELSA-Brasil). Braz J Med Biol Res 2016;49(12):e5734-e. [Crossref]

25. Massot A, Giralt D, Penalba A, Garcia-Berrocoso T, Navarro-Sobrino M, Arenillas JF, et al. Predictive value of ankle-brachial index and PAI-1 in symptomatic intracranial atherosclerotic disease recurrence. Atherosclerosis 2014;233(1):186-9. [Crossref]

26. Purroy F, Coll B, Oro M, Seto E, Pinol-Ripoll G, Plana A, et al. Predictive value of ankle brachial index in patients with acute ischaemic stroke. Eur J Neurol 2010;17(4):602-6. [Crossref]

27. Sen S, Lynch DR, Jr., Kaltsas E, Simmons J, Tan WA, Kim J, et al. Association of asymptomatic peripheral arterial disease with vascular events in patients with stroke or transient ischemic attack. Stroke 2009;40(11):3472-7. [Crossref]

28. Milionis H, Vemmou A, Ntaios G, Makaritsis K, Koroboki E, Papavasileiou $V$, et al. Ankle-brachial index long-term 
outcome after first-ever ischaemic stroke. Eur J Neurol 2013;20(11):1471-8. [Crossref]

29. Tziomalos K, Giampatzis V, Bouziana S, Pavlidis A, Spanou M, Papadopoulou $M$, et al. Predictive value of the ankle brachial index in patients with acute ischemic stroke. VASA Zeitschrift fur Gefasskrankheiten 2014;43(1):55-61. [Crossref]

30. Hofstede A, Wollaars H, van Drongelen J. A clinical evaluation of blood pressure measurement by iHealth BP5 in pregnancy. Pregnancy Hypertens. 2019;17:69-74. [Crossref]

31. Pickering TG, Hall JE, Appel LJ, Falkner BE, Graves J, Hill MN, et al. Recommendations for blood pressure measurement in humans and experimental animals: part 1: blood pressure measurement in humans: a statement for professionals from the Subcommittee of Professional and Public Education of the American Heart Association Council on High Blood Pressure Research. Circulation 2005;111(5):697-716. [Crossref]

32. Roerecke M, Kaczorowski J, Myers MG. Comparing Automated Office Blood Pressure Readings With Other Methods of Blood Pressure Measurement for Identifying Patients With Possible Hypertension: A Systematic Review and Meta-analysis. JAMA Intern Med 2019;179(3):351-62. [Crossref]

33. Kleefstra N, Houweling ST, Meyboom-de Jong B, Bilo HJ. Measuring the blood pressure in both arms is of little use; longitudinal study into blood pressure differences between both arms and its reproducibility in patients with diabetes mellitus type 2. Nederlands tijdschrift voor geneeskunde 2007;151:1509-14.

34. Tabachnick B, Fidell L. Using Multivariate Statistics: Pearson, Boston; 2013.

35. Menanga A, Edie S, Nkoke C, Boombhi J, Musa AJ, Mfeukeu LK, et al. Factors associated with blood pressure control amongst adults with hypertension in Yaounde, Cameroon: a cross-sectional study. Cardiovasc Diagn Ther 2016;6(5):43945. [Crossref]

36. Sheppard JP, Albasri A, Franssen M, Fletcher B, Pealing L, Roberts $N$, et al. Defining the relationship between arm and leg blood pressure readings: a systematic review and meta-analysis. J. Hypertens 2019;37(4):660-70. [Crossref]

37. Kawabe $\mathrm{H}$, Saito I. Influence of age and sex on prevalence of masked hypertension determined from home blood pressure measurements. Hum Hypertens 2007;21(1):94-5. [Crossref]
38. Pinna G, Pascale C, La Regina M, Orlandini F. Hypertension in the elderly. Italian J Med 2012;6:285-94. [Crossref]

39. Tak YJ, Kim JY, Lee SY, Lee JG, Jeong DW, Yi YD, et al. Association of inter-arm blood pressure difference with atherosclerosis in patients without cardiovascular diseases. J Korean Soc Hypertens 2013;19(3):71-80. [Crossref]

40. Arnett DK, Tang W, Province MA, Oberman A, Ellison RC, Morgan $D$, et al. Interarm differences in seated systolic and diastolic blood pressure: the Hypertension Genetic Epidemiology Network study. J Hypertens 2005;23(6):1141-7. [Crossref]

41. Singer AJ, Hollander JE. Blood pressure. Assessment of interarm differences. Arch Intern Med 1996;156(17):2005-8. [Crossref]

42. Brown CD, Higgins M, Donato KA, Rohde FC, Garrison R, Obarzanek $E$, et al. Body mass index and the prevalence of hypertension and dyslipidemia. Obes Res 2000;8(9):605-19. [Crossref]

43. Dua S, Bhuker M, Sharma P, Dhall M, Kapoor S. Body mass index relates to blood pressure among adults. N Am J Med Sci 2014;6(2):89-95. [Crossref]

44. Rosenberger J, McCrudden S, McCullough C, Wang L, Kime J, Albert NM. Factors associated with inter-arm blood pressure differences in patients admitted to critical care units. Heart Lung 2018;47(2):100-6. [Crossref]

45. Graves JW, Grossardt BR. Discarding the first of three nurse-auscultatory or oscillometric blood pressure measurements does not improve the association of office blood pressure with ABPM. Blood Press Monit 2010;15(3):146-51. [Crossref]

46. Shahbabu B, Dasgupta A, Sarkar K, Sahoo SK. Which is More Accurate in Measuring the Blood Pressure? A Digital or an Aneroid Sphygmomanometer. J Clin Diagn Res 2016;10:LC11LC4. [Crossref]

47. Sutton-Tyrrell K, Venkitachalam L, Kanaya AM, Boudreau $\mathrm{R}$, Harris T, Thompson T, et al. Relationship of Ankle Blood Pressures to Cardiovascular Events in Older Adults. Stroke 2008;39(3):863-9. [Crossref]

48. Newman AB, Siscovick DS, Manolio TA, Polak J, Fried LP, Borhani NO, et al. ankle-arm index as a marker of atherosclerosis in the cardiovascular health study. Circulation 1993;88(3):837-45. [Crossref] 